\title{
A STUDY ON THE NARCOTIC ACTION OF THE SHORT CHAIN FATTY ACIDS 1
}

\author{
BY FREDERICK E. SAMSON, JR., NANCY DAHL, AND DENNIS R. DAHL
}

(From the Department of Physiology, University of Kansas, Lawrence, Kan.)

(Submitted for publication October 3, 1955; accepted July 5, 1956)

That the short chain fatty acids have an inhibitory action on many metabolic reactions has been shown in baker's yeast (1), bacteria (2-4), fungi (5), cell-free yeast extracts (1), and mammalian muscle (6). However, the effects of the short chain fatty acids on "intact" animals have not been studied in similar detail, except for a few studies on the toxicity of butyrate ( 7$), \beta$-hydroxybutyrate $(8,9)$, acetone $(10)$ and acetoacetate (11). The present work is a study of the narcotic action of the neutralized salts of the short chain fatty acids upon "intact" rats.

\section{METHODS}

Solutions of the fatty acid salts were prepared daily by adding a weighed amount of the acid (Fisher Scientific Co.) to distilled water and neutralizing it to a $\mathrm{pH}$ of 7.4 with 20 per cent $\mathrm{w} / \mathrm{v} \mathrm{NaOH}$. The $\mathrm{pH}$ was determined with a glass electrode $\mathrm{pH}$ meter while air bubbled through the solution to insure adequate mixing. In this connection, $\mathrm{pH}$ determinations are subject to error because these acids tend to form two phase systems and colloidal gels. In the present experiments care was taken to neutralize all the free fatty acid and only homogeneous preparations were used. The concentration of the fatty acid anion is specified in the individual cases. The $\beta$-hydroxybutyrate was purchased as the sodium salt (Nutritional Biochemical Corp.) and solutions were prepared by dissolving a weighed amount in distilled water and bringing it to a $\mathrm{pH}$ of 7.4.

The rats used in these experiments were females from a Sprague-Dawley strain maintained on Nutrena dog food nuggets and weighing between 50 and 200 grams. They were fasted 24 hours before experimentation and weighed immediately prior to the fatty acid injection. For species comparisons, mice, guinea pigs, dogs, chicks and frogs were used; however, detailed data were collected only with rats.

Nephrectomized rats were prepared according to the directions of Farris and Griffith (12). With the animal under ether anesthesia a dorsal midline incision was made, the renal connections isolated and tied off at the hilum, then the kidney excised. With the operation concluded,

1 Supported by a research grant from the University of Kansas General Research Appropriation and the Nat'l Insts. of Health Grant A-321, United States Public Health Service. the incision was closed by two or three skin sutures and the area sealed with collodion. Rats were made alloxandiabetic by a tail vein injection of alloxan monohydrate (Nutritional Biochemical Corp.), $40 \mathrm{mg}$. per Kg. body weight. Two weeks later, the animals were fasted 24 hours and then urine samples collected for glucose analysis. Only those rats with glucose in the urine greater than 1 per cent were considered alloxan-diabetic.

To determine whether or not an animal was conscious the animal was placed on its back at one minute intervals after the fatty acid solution was injected. If it did not right itself within ten seconds, it was judged unconscious. With most animals, and rats in particular, this gives a reproducible end point.

Urine analyses for glucose and acetone were carried out with commercially obtained tablets (Ames Co.). The determination of the fatty acids in the urine was done chromatographically (13).

\section{RESULTS AND DISCUSSION}

Intravenous or intraperitoneal injection of the sodium salts of the short chain fatty acids produces unconsciousness in rats, frogs, chicks, mice, dogs and guinea pigs. The effect of various amounts and concentrations of the short chain fatty acids given intraperitoneally in rats is presented in Table I. As can be seen, unconsciousness occurs in two to forty minutes after injection and may persist for as long as an hour. The amount of fatty acid anion which will produce unconsciousness in 50 per cent of a sample of rats $\left(E_{b 0}\right)$ was determined by plotting the per cent of each group of animals that lost consciousness against the amount injected and then selecting the amount which corresponded to 50 per cent (14).

There is a definite relationship between the amount of the fatty acid which will produce unconsciousness and the carbon chain length of the compound. As might be expected, the $E_{50}$ decreases rapidly with the increase in chain length (Figure 1).

It should be noted that the $E_{50}$ for a given fatty acid depends upon the concentration of the acid as well as its chain length. This point is demonstrated in Figure 2 where the $E_{50}$ for octanoate 
FREDERICK E. SAMSON, JR., NANCY DAHL, AND DENNIS R. DAHL

TABLE I

The effect of the intraperitoneal injection of the sodium salts of the short chain fatty acids

\begin{tabular}{|c|c|c|c|c|c|c|c|}
\hline $\begin{array}{l}\text { Rat } \\
\text { no. }\end{array}$ & Fatty acid & Conc. & $\begin{array}{c}\text { Amount } \\
\text { injected } \\
m M / K \boldsymbol{M} .\end{array}$ & Response & $\begin{array}{c}\text { Time } \\
\text { until } \\
\text { unconscious } \\
\text { minutes }\end{array}$ & $\begin{array}{c}\text { Duration } \\
\text { unconscious } \\
\text { minutes }\end{array}$ & $\underset{m M / K g}{E_{50}}$ \\
\hline $\begin{array}{l}1 \\
2 \\
3 \\
4 \\
5\end{array}$ & Acetate & 1.0 & $\begin{array}{l}20 \\
21 \\
30 \\
33 \\
36\end{array}$ & $\begin{array}{l}\text { None } \\
\text { None } \\
\text { None } \\
\text { None } \\
\text { None }\end{array}$ & & & \\
\hline 6 & & 2.0 & 56 & Unconsc. & 18 & 15 (died) & \\
\hline $\begin{array}{r}7 \\
8 \\
9 \\
10 \\
11 \\
12 \\
13 \\
14 \\
15 \\
16\end{array}$ & Propionate & 1.0 & $\begin{array}{l}28 \\
28 \\
28 \\
28 \\
28 \\
30 \\
30 \\
30 \\
30 \\
30\end{array}$ & $\begin{array}{l}\text { None } \\
\text { None } \\
\text { None } \\
\text { Unconsc. } \\
\text { Unconsc. } \\
\text { None } \\
\text { None } \\
\text { Unconsc. } \\
\text { Unconsc. } \\
\text { Unconsc. }\end{array}$ & $\begin{array}{l}18 \\
20 \\
\\
20 \\
20 \\
18\end{array}$ & $\begin{array}{r}18 \\
36 \\
\\
4 \\
4 \\
4 \\
18\end{array}$ & 29.0 \\
\hline $\begin{array}{l}17 \\
18 \\
19 \\
20 \\
21 \\
22 \\
23 \\
24 \\
25 \\
26 \\
27 \\
28 \\
29 \\
30 \\
31 \\
32 \\
33 \\
34 \\
35 \\
36\end{array}$ & Butyrate & 1.0 & $\begin{array}{l}12.5 \\
12.5 \\
12.5 \\
12.5 \\
12.5 \\
14.0 \\
14.0 \\
14.0 \\
14.0 \\
14.0 \\
16.0 \\
16.0 \\
16.0 \\
16.0 \\
16.0 \\
20.0 \\
20.0 \\
20.0 \\
20.0 \\
20.0\end{array}$ & $\begin{array}{l}\text { None } \\
\text { None } \\
\text { None } \\
\text { None } \\
\text { None } \\
\text { None } \\
\text { None } \\
\text { None } \\
\text { Unconsc. } \\
\text { Unconsc. } \\
\text { Unconsc. } \\
\text { Unconsc. } \\
\text { Unconsc. } \\
\text { Unconsc. } \\
\text { Unconsc. } \\
\text { Uncons. } \\
\text { Unconsc. } \\
\text { Unconsc. } \\
\text { Unconsc. } \\
\text { Unconsc. }\end{array}$ & $\begin{array}{r}11 \\
11 \\
14 \\
8 \\
8 \\
7 \\
7 \\
11 \\
9 \\
8 \\
7 \\
6\end{array}$ & $\begin{array}{r}2 \\
3 \\
6 \\
20 \\
21 \\
11 \\
20 \\
5 \\
51 \\
40 \\
50 \\
42\end{array}$ & 14.2 \\
\hline $\begin{array}{l}37 \\
38 \\
39 \\
40 \\
41 \\
42 \\
43 \\
44 \\
45 \\
46 \\
47 \\
48 \\
49\end{array}$ & & 0.5 & $\begin{array}{l}20.0 \\
20.0 \\
20.0 \\
20.0 \\
20.0 \\
23.0 \\
23.0 \\
23.0 \\
23.0 \\
26.0 \\
26.0 \\
26.0 \\
26.0\end{array}$ & $\begin{array}{l}\text { None } \\
\text { None } \\
\text { None } \\
\text { None } \\
\text { None } \\
\text { None } \\
\text { None } \\
\text { Unconsc. } \\
\text { Unconsc. } \\
\text { Unconsc. } \\
\text { Unconsc. } \\
\text { Unconsc. } \\
\text { Unconsc. }\end{array}$ & $\begin{array}{l}24 \\
14 \\
14 \\
12 \\
12 \\
11\end{array}$ & $\begin{array}{r}2 \\
12 \\
1 \\
5 \\
7 \\
9\end{array}$ & 23.0 \\
\hline $\begin{array}{l}\mathbf{5 0} \\
\mathbf{5 1} \\
\mathbf{5 2} \\
\mathbf{5 3} \\
\mathbf{5 4} \\
\mathbf{5 5} \\
\mathbf{5 6} \\
\mathbf{5 7} \\
\mathbf{5 8}\end{array}$ & Valerate & 0.67 & $\begin{array}{l}18 \\
18 \\
18 \\
18 \\
18 \\
18 \\
18 \\
18 \\
18\end{array}$ & $\begin{array}{l}\text { None } \\
\text { None } \\
\text { Unconsc. } \\
\text { Unconsc. } \\
\text { Unconsc. } \\
\text { Unconsc. } \\
\text { Unconsc. } \\
\text { Unconsc. } \\
\text { Unconsc. }\end{array}$ & $\begin{array}{l}32 \\
22 \\
22 \\
22 \\
22 \\
21 \\
20\end{array}$ & $\begin{array}{r}6 \\
28 \\
22 \\
26 \\
30 \\
44 \\
28\end{array}$ & 18.0 \\
\hline $\begin{array}{l}59 \\
60 \\
61 \\
62\end{array}$ & & 0.50 & $\begin{array}{l}18 \\
18 \\
18 \\
18\end{array}$ & $\begin{array}{l}\text { None } \\
\text { None } \\
\text { None } \\
\text { None }\end{array}$ & & & \\
\hline
\end{tabular}


TABLE I-Continued

\begin{tabular}{|c|c|c|c|c|c|c|c|}
\hline $\begin{array}{l}\text { Rat } \\
\text { no. }\end{array}$ & Fatty acid & Conc. & $\begin{array}{l}\text { Amount } \\
\text { injected } \\
\mathbf{m M} / \mathbf{K}_{\mathbf{g}} .\end{array}$ & Response & $\begin{array}{c}\text { Time } \\
\text { until } \\
\text { unconscious } \\
\text { minutes }\end{array}$ & $\begin{array}{c}\text { Duration } \\
\text { unconscious } \\
\text { minutes }\end{array}$ & $\underset{m M / K_{g}}{E_{50}}$ \\
\hline $\begin{array}{l}63 \\
64 \\
65 \\
66 \\
67 \\
68 \\
69 \\
70 \\
71 \\
72\end{array}$ & Valerate & & $\begin{array}{l}18 \\
20 \\
20 \\
20 \\
20 \\
20 \\
22 \\
22 \\
22 \\
22\end{array}$ & $\begin{array}{l}\text { Unconsc. } \\
\text { None } \\
\text { None } \\
\text { Unconsc. } \\
\text { Unconsc. } \\
\text { Unconsc. } \\
\text { Unconsc. } \\
\text { Unconsc. } \\
\text { Unconsc. } \\
\text { Unconsc. }\end{array}$ & $\begin{array}{l}28 \\
\\
38 \\
18 \\
16 \\
24 \\
16 \\
14 \\
12\end{array}$ & $\begin{array}{r}4 \\
\\
10 \\
30 \\
16 \\
8 \\
8 \\
44 \\
32\end{array}$ & 19.0 \\
\hline $\begin{array}{l}73 \\
74 \\
75 \\
76 \\
77 \\
78 \\
79 \\
80 \\
81 \\
82 \\
83 \\
84 \\
85 \\
86 \\
87 \\
88 \\
89 \\
90 \\
91 \\
92\end{array}$ & Caproate & 0.50 & $\begin{array}{l}12 \\
12 \\
12 \\
12 \\
12 \\
14 \\
14 \\
14 \\
14 \\
14 \\
15 \\
15 \\
15 \\
15 \\
15 \\
16 \\
16 \\
16 \\
16 \\
16\end{array}$ & $\begin{array}{l}\text { None } \\
\text { None } \\
\text { None } \\
\text { None } \\
\text { Unconsc. } \\
\text { None } \\
\text { None } \\
\text { None } \\
\text { None } \\
\text { Unconsc. } \\
\text { None } \\
\text { None } \\
\text { Unconsc. } \\
\text { Unconsc. } \\
\text { Unconsc. } \\
\text { Unconsc. } \\
\text { Unconsc. } \\
\text { Unconsc. } \\
\text { Unconsc. } \\
\text { Unconsc. }\end{array}$ & $\begin{array}{l}9 \\
\\
8 \\
\\
\\
9 \\
8 \\
6 \\
9 \\
7 \\
6 \\
5 \\
4\end{array}$ & $\begin{array}{r}2 \\
\\
\\
6 \\
\\
5 \\
4 \\
6 \\
7 \\
7 \\
10 \\
9 \\
10\end{array}$ & 15.0 \\
\hline $\begin{array}{r}93 \\
94 \\
95 \\
96 \\
97 \\
98 \\
99 \\
100 \\
101 \\
102 \\
103 \\
104 \\
105 \\
106 \\
107\end{array}$ & Heptanoate & 0.50 & $\begin{array}{l}5 \\
5 \\
5 \\
5 \\
5 \\
6 \\
6 \\
6 \\
6 \\
6 \\
7 \\
7 \\
7 \\
7 \\
7\end{array}$ & $\begin{array}{l}\text { None } \\
\text { None } \\
\text { None } \\
\text { None } \\
\text { None } \\
\text { None } \\
\text { None } \\
\text { None } \\
\text { Unconsc. } \\
\text { Unconsc. } \\
\text { None } \\
\text { Unconsc. } \\
\text { Unconsc. } \\
\text { Unconsc. } \\
\text { Unconsc. }\end{array}$ & $\begin{array}{l}5 \\
5 \\
5 \\
5 \\
5 \\
6\end{array}$ & $\begin{array}{l}5 \\
6 \\
5 \\
6 \\
7 \\
7\end{array}$ & 6.2 \\
\hline $\begin{array}{l}108 \\
109 \\
110 \\
111 \\
112\end{array}$ & Octanoate & 1.0 & $\begin{array}{l}2 \\
2 \\
2 \\
2 \\
2\end{array}$ & $\begin{array}{l}\text { None } \\
\text { None } \\
\text { Unconsc. } \\
\text { Unconsc. } \\
\text { Unconsc. }\end{array}$ & $\begin{array}{l}4 \\
3 \\
2\end{array}$ & $\begin{array}{r}4 \\
6 \\
10\end{array}$ & 2.0 \\
\hline $\begin{array}{l}113 \\
114 \\
115 \\
116 \\
117 \\
118 \\
119 \\
120 \\
121 \\
122 \\
123 \\
124 \\
125 \\
126 \\
127\end{array}$ & & 0.5 & $\begin{array}{l}3.4 \\
3.4 \\
3.4 \\
3.4 \\
3.4 \\
3.6 \\
3.6 \\
3.6 \\
3.6 \\
3.6 \\
3.8 \\
3.8 \\
3.8 \\
3.8 \\
3.8\end{array}$ & $\begin{array}{l}\text { None } \\
\text { None } \\
\text { None } \\
\text { None } \\
\text { None } \\
\text { None } \\
\text { None } \\
\text { None } \\
\text { Unconsc. } \\
\text { Unconsc. } \\
\text { None } \\
\text { None } \\
\text { Unconsc. } \\
\text { Unconsc. } \\
\text { Unconsc. }\end{array}$ & $\begin{array}{l}5 \\
5 \\
\\
5 \\
5 \\
5\end{array}$ & $\begin{array}{l}2 \\
3 \\
\\
3 \\
5 \\
5\end{array}$ & 3.7 \\
\hline
\end{tabular}


TABLE I-Continued

\begin{tabular}{|c|c|c|c|c|c|c|c|}
\hline $\begin{array}{l}\text { Rat } \\
\text { no. }\end{array}$ & Fatty acid & $\underset{M}{\text { Conc. }}$ & $\begin{array}{l}\text { Amount } \\
\text { injected } \\
\mathbf{m} \boldsymbol{M} / \boldsymbol{K} \mathbf{g} .\end{array}$ & Response & $\underset{\substack{\text { Time } \\
\text { until } \\
\text { unconscious } \\
\text { minutes }}}{\text { ming }}$ & $\begin{array}{c}\text { Duration } \\
\text { unconscious } \\
\text { minutes }\end{array}$ & $\underset{m M / K_{g} .}{E_{s 0}}$ \\
\hline $\begin{array}{l}128 \\
129\end{array}$ & Octanoate & & $\begin{array}{l}5.0 \\
7.5\end{array}$ & $\begin{array}{l}\text { Unconsc. } \\
\text { Unconsc. }\end{array}$ & $\begin{array}{l}5 \\
3\end{array}$ & $\begin{array}{r}7 \\
32\end{array}$ & \\
\hline $\begin{array}{l}130 \\
131 \\
132 \\
133 \\
134\end{array}$ & & 0.1 & $\begin{array}{l}6.0 \\
6.0 \\
6.0 \\
6.0 \\
6.0\end{array}$ & $\begin{array}{l}\text { Unconsc. } \\
\text { Unconsc. } \\
\text { Unconsc. } \\
\text { Unconsc. } \\
\text { Unconsc. }\end{array}$ & $\begin{array}{r}11 \\
10 \\
9 \\
8 \\
7\end{array}$ & $\begin{array}{r}12 \\
14 \\
22 \\
>32 \\
>32\end{array}$ & \\
\hline $\begin{array}{l}135 \\
136 \\
137 \\
138 \\
139 \\
140 \\
141 \\
142 \\
143 \\
144 \\
145 \\
146 \\
147 \\
148 \\
149\end{array}$ & Pelargonate & 0.3 & $\begin{array}{l}2.5 \\
2.5 \\
2.5 \\
2.5 \\
2.5 \\
2.7 \\
2.7 \\
2.7 \\
2.7 \\
2.7 \\
3.0 \\
3.0 \\
3.0 \\
3.0 \\
3.0\end{array}$ & $\begin{array}{l}\text { None } \\
\text { None } \\
\text { None } \\
\text { None } \\
\text { None } \\
\text { None } \\
\text { None } \\
\text { None } \\
\text { None } \\
\text { Unconsc. } \\
\text { Unconsc. } \\
\text { Unconsc. } \\
\text { Unconsc. } \\
\text { Unconsc. } \\
\text { Unconsc. }\end{array}$ & $\begin{array}{l}8 \\
5 \\
4 \\
3 \\
3 \\
3\end{array}$ & $\begin{array}{r}2 \\
4 \\
8 \\
6 \\
10 \\
10\end{array}$ & 2.8 \\
\hline $\begin{array}{l}150 \\
151 \\
152 \\
153 \\
154 \\
155 \\
156 \\
157 \\
158 \\
159 \\
160 \\
161 \\
162 \\
163 \\
164 \\
165 \\
166 \\
167 \\
168 \\
169\end{array}$ & Caprate & 0.1 & $\begin{array}{l}2.8 \\
2.8 \\
2.8 \\
2.8 \\
2.8 \\
3.2 \\
3.2 \\
3.2 \\
3.2 \\
3.2 \\
3.4 \\
3.4 \\
3.4 \\
3.4 \\
3.4 \\
3.6 \\
3.6 \\
3.6 \\
3.6 \\
3.6\end{array}$ & $\begin{array}{l}\text { None } \\
\text { None } \\
\text { None } \\
\text { None } \\
\text { None } \\
\text { None } \\
\text { None } \\
\text { None } \\
\text { None } \\
\text { Unconsc. } \\
\text { None } \\
\text { None } \\
\text { Unconsc. } \\
\text { Unconsc. } \\
\text { Unconsc. } \\
\text { Unconsc. } \\
\text { Unconsc. } \\
\text { Unconsc. } \\
\text { Unconsc. } \\
\text { Unconsc. }\end{array}$ & $\begin{array}{l}14 \\
\\
7 \\
4 \\
4 \\
7 \\
5 \\
5 \\
5 \\
7\end{array}$ & $\begin{array}{l}2 \\
\\
1 \\
4 \\
6 \\
1 \\
3 \\
3 \\
6 \\
6\end{array}$ & 3.3 \\
\hline
\end{tabular}

as a function of concentration is presented. This pronounced effect of concentration upon the $E_{50}$ is probably a result of a rapid disposal of the fatty acid anion and the influence of concentration upon the rate of absorption from the injection site. With propionate, solutions of low concentration are not effective enough to be adequately studied, whereas with pelargonate and caprate, only solutions of low concentration are sufficiently homogeneous to give reliable results. Therefore, the action of the three, nine and ten carbon members (propionate, pelargonate, and caprate respectively) cannot be quantitatively compared. However, their effectiveness corresponds with the general pattern as seen in Table I.
At the two carbon chain length the narcotic action becomes so weak that large quantities of acetate can be administered without the characteristic effect exhibited by the other acids. The injection of about 56 millimoles per $\mathrm{Kg}$. body weight of $2 \mathrm{M}$ sodium acetate will cause unconsciousness, but the pattern of the response is different. Following the injection of the other fatty acids there is reduced muscular tone and activity, whereas after the injection of the sodium acetate severe muscular spasms and convulsive movements occur. It is interesting to note that the intraperitoneal injection of the same amount ( 56 millimoles per $\mathrm{Kg}$.) of $2 \mathrm{M} \mathrm{NaCl}$ produces the same type of response: that is, a few minutes after the injection the rat 


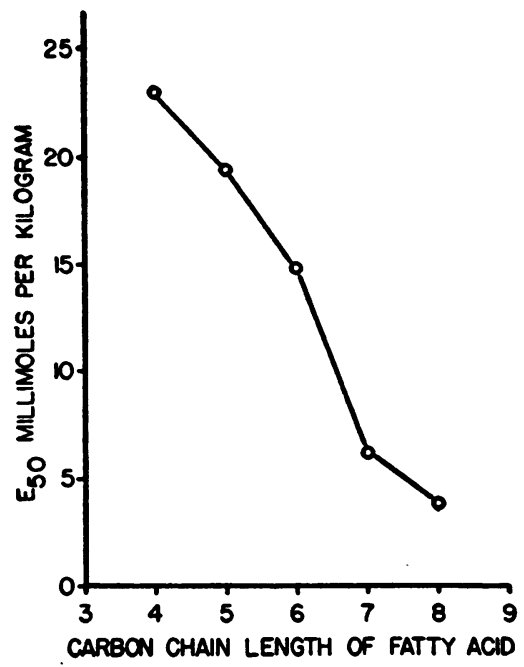

Fig. 1. Eso of Fatty Acid Anion as a Function of Chain Length

All acids neutralized to $\mathrm{pH} 7.4$; conc. $0.5 \mathrm{M}$; given intraperitoneally. Data taken from Table I.

shows muscular twitching which becomes progressively increased until severe muscular spasms cause the animal to thrash about violently. The animal loses consciousness and dies, usually within an hour after the injection. The similarity of the response from the $2 \mathrm{M}$ sodium acetate injection to that from the $2 \mathrm{M} \mathrm{NaCl}$ suggests that the mechanism of action here is related to the sodium ion rather than the acetate anion. This effect of high sodium ion has been reported by Ulrich and Shternov (15).

As might be expected, the length of time from injection until unconsciousness, the $E_{50}$, and the length of time of unconsciousness also depend to some extent upon the rate of absorption from the injected site. Consequently, subcutaneous administration is not very effective and nothing more than a sluggishness occurs. Further, the forced feeding of as much as twice the $E_{50}$ will not even produce sluggishness. On the other hand, when the compounds are given intravenously unconsciousness occurs within a few seconds after the injection and with somewhat less than half of the amount necessary to cause unconsciousness with the intraperitoneal route (Table II).

\section{Hemolysis}

As it is common knowledge that washed red blood cells will hemolyze when suspended in a sufficiently concentrated solution of the fatty acid anions (16), it seemed reasonable to consider what part hemolysis might play in the reactions which follow fatty acid injection. Accordingly, we have drawn blood by cardiac puncture from rats made unconscious from a fatty acid injection and examined it grossly after centrifugation: in no instance was hemolysis noted.

\section{Kidneys.}

The fatty acids and some of their metabolic products appear in the urine following their injection (Table III). From these findings we reasoned that the recovery from the narcotic action of the compounds rested mainly in excretion by the kidneys. But this idea was not supported by experiments on nephrectomized rats. The $E_{50}$ and the length of time until recovery in nephrectomized rats seem to be of the same order of magnitude as in the control rats (compare Table IV with Table I).

\section{Influence of $(O H)$ group in carbon chain}

To determine if the introduction of a hydroxyl group into the carbon chain would alter the action, we injected lactate and $\beta$-hydroxybutyrate and compared their effectiveness with the corresponding fatty acids, propionate and butyrate. The results show that the hydroxy compounds are much less effective (Table V): In fact, the $E_{50}$ for $1 \mathrm{M}$ lactate and $\beta$-hydroxybutyrate could not be de-

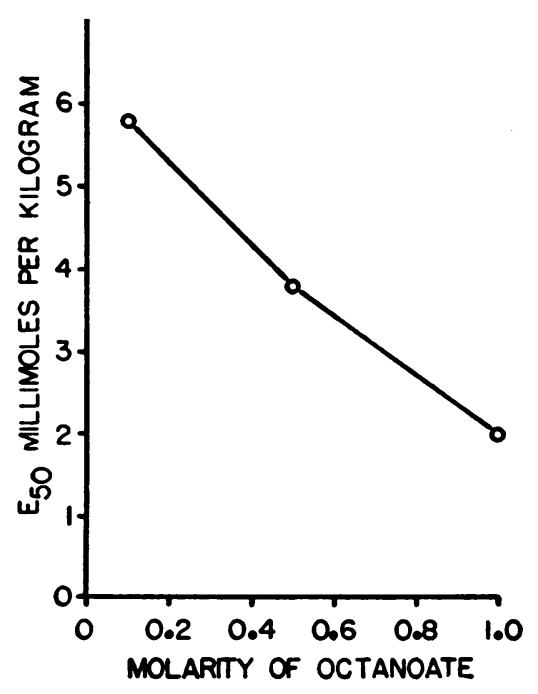

Fig. 2. $E_{\text {so }}$ of Sodium Octanoate as a Function of Concentration

$\mathrm{pH} 7.4$; given intraperitoneally. Data taken from Table I. 
FREDERICK E. SAMSON, JR., NANCY DAHL, AND DENNIS R. DAHL

TABLE II

The effect of the injection site on the response to the sodium salts of the fatty acids

\begin{tabular}{|c|c|c|c|c|c|c|c|}
\hline $\begin{array}{l}\text { Rat } \\
\text { no. }\end{array}$ & $\begin{array}{l}\text { Injection } \\
\text { site }\end{array}$ & Fatty acid & Conc. & $\begin{array}{c}\text { Amount } \\
\text { injected } \\
m \boldsymbol{M M} / \mathbf{K} .\end{array}$ & Response & $\begin{array}{c}\text { Time } \\
\text { until } \\
\text { unconsc. }\end{array}$ & $\begin{array}{c}\text { Duration } \\
\text { of } \\
\text { unconsc. }\end{array}$ \\
\hline $\begin{array}{l}170 \\
171 \\
172\end{array}$ & $\begin{array}{l}\text { Intravenous } \\
\text { (tail vein) }\end{array}$ & Propionate & 1.0 & $\begin{array}{l}12.3 \\
18.0 \\
19.0\end{array}$ & $\begin{array}{l}\text { None } \\
\text { Unconsc. } \\
\text { Unconsc. }\end{array}$ & $\begin{array}{l}5 \text { sec. } \\
5 \text { sec. }\end{array}$ & $\begin{array}{l}\text { Died } \\
25 \mathrm{sec} .\end{array}$ \\
\hline $\begin{array}{l}173 \\
174 \\
175 \\
176\end{array}$ & & Valerate & 1.0 & $\begin{array}{r}2.0 \\
8.8 \\
10.0 \\
12.0\end{array}$ & $\begin{array}{l}\text { None } \\
\text { None } \\
\text { Unconsc. } \\
\text { Unconsc. }\end{array}$ & $\begin{array}{l}<1 \text { min. } \\
<1 \text { min. }\end{array}$ & $\begin{array}{l}2 \mathrm{~min} . \\
2 \mathrm{~min} .\end{array}$ \\
\hline $\begin{array}{l}177 \\
178\end{array}$ & & Caproate & 0.5 & $\begin{array}{l}5.6 \\
6.2\end{array}$ & $\begin{array}{l}\text { None } \\
\text { Unconsc. }\end{array}$ & $30 \mathrm{sec}$. & $3 \mathrm{~min}$. \\
\hline $\begin{array}{l}179 \\
180 \\
181\end{array}$ & & Heptanoate & 0.4 & $\begin{array}{l}1.6 \\
2.0 \\
2.0\end{array}$ & $\begin{array}{l}\text { None } \\
\text { Unconsc. } \\
\text { Unconsc. }\end{array}$ & $\begin{array}{r}<30 \text { sec. } \\
5 \text { sec. }\end{array}$ & $\begin{array}{r}<30 \text { sec. } \\
55 \text { sec. }\end{array}$ \\
\hline $\begin{array}{l}182 \\
183 \\
184 \\
185 \\
186\end{array}$ & & Octanoate & 0.5 & $\begin{array}{l}0.8 \\
0.8 \\
1.0 \\
1.2 \\
1.5\end{array}$ & $\begin{array}{l}\text { Unconsc. } \\
\text { None } \\
\text { Unconsc. } \\
\text { Unconsc. } \\
\text { Unconsc. }\end{array}$ & $\begin{array}{r}5 \text { sec. } \\
5 \text { sec. } \\
20 \text { sec. } \\
5 \text { sec. }\end{array}$ & $\begin{array}{l}40 \text { sec. } \\
1 \text { min. } \\
1 \text { min. } \\
3 \text { min. }\end{array}$ \\
\hline $\begin{array}{l}187 \\
188 \\
189 \\
190 \\
191\end{array}$ & & Pelargonate & 0.3 & $\begin{array}{l}0.5 \\
0.5 \\
0.7 \\
0.7 \\
0.7\end{array}$ & $\begin{array}{l}\text { None } \\
\text { None } \\
\text { Unconsc. } \\
\text { Unconsc. } \\
\text { Unconsc. }\end{array}$ & $\begin{array}{l}5 \text { sec. } \\
5 \text { sec. } \\
5 \text { sec. }\end{array}$ & $\begin{array}{r}160 \mathrm{sec} . \\
6 \mathrm{~min} .\end{array}$ \\
\hline $\begin{array}{l}192 \\
193 \\
194\end{array}$ & & Caprate & 0.1 & $\begin{array}{l}0.5 \\
0.6 \\
0.8\end{array}$ & $\begin{array}{l}\text { None } \\
\text { Unconsc. } \\
\text { Unconsc. }\end{array}$ & $\begin{array}{l}20 \mathrm{sec} . \\
10 \mathrm{sec} .\end{array}$ & $\begin{array}{l}1 \mathrm{~min} . \\
95 \mathrm{sec} \text {. }\end{array}$ \\
\hline 195 & Subcutaneous & Valerate & 1.0 & 22.0 & None & & \\
\hline $\begin{array}{l}196 \\
197 \\
198 \\
199\end{array}$ & $\begin{array}{l}\text { Gastro- } \\
\text { intestinal } \\
\text { (forced } \\
\text { feeding) }\end{array}$ & Valerate & 1.0 & $\begin{array}{l}22.0 \\
22.0 \\
26.0 \\
35.0\end{array}$ & $\begin{array}{l}\text { None } \\
\text { None } \\
\text { None } \\
\text { None }\end{array}$ & & \\
\hline
\end{tabular}

termined because a definitive state of unconsciousness did not occur. Instead, convulsions similar to those seen after the injection of $\mathrm{NaCl}$ discussed earlier resulted. With $1 \mathrm{M} \beta$-hydroxybutyrate

TABLE III

Urine analysis following intraperitoneal injection of the fatty acid salts*

\begin{tabular}{|c|c|c|c|}
\hline \multirow{2}{*}{$\begin{array}{c}\text { Fatty acid } \\
\text { injected }\end{array}$} & \multicolumn{3}{|c|}{ Urine analysis } \\
\hline & $\begin{array}{c}\text { Fatty acid } \\
\%\end{array}$ & $\underset{\%}{\text { Glucose }}$ & $\begin{array}{c}\text { Ketones } \\
\%\end{array}$ \\
\hline $\begin{array}{l}\text { Propionate } \\
(30 \mathrm{mM} / \mathrm{Kg.})\end{array}$ & & 1.0 & 0.05 \\
\hline $\begin{array}{l}\text { Butyrate } \\
(28 m M / K g .)\end{array}$ & $0.2-0.3$ & 0.0 & 2.0 \\
\hline $\begin{array}{l}\text { Valerate } \\
(24 m M / K g .)\end{array}$ & $0.4-0.7$ & 1.0 & 0.0 \\
\hline $\begin{array}{l}\text { Caproate } \\
\left(13 \mathrm{mM} / K_{g .}\right)\end{array}$ & 0.2 & 0.0 & 2.0 \\
\hline $\begin{array}{l}\text { Octanoate } \\
(3.9 m M / K g .)\end{array}$ & $\begin{array}{l}0.0 \text { Octanoate } \\
0.1 \text { Butyrate }\end{array}$ & & \\
\hline
\end{tabular}

* Rats fasted 24 hours before experiment. Urine collected for 6 to 12 hours after injection. these convulsions occurred after the administration of about 40 millimoles per $\mathrm{Kg}$. body weight, whereas the $E_{s 0}$ of $1 \mathrm{M}$ butyrate is 14.2 millimoles per $\mathrm{Kg}$. body weight.

\section{Alloxan-diabetic rats}

Although the alloxan-diabetic rat does not develop ketosis as is seen in severe human diabetes (17), there is some disturbance of fat metabolism in alloxan diabetes (18) thus it seemed worthwhile to ascertain the susceptibility of alloxandiabetic rats to the narcotic action of the fatty acid anions. The results of these experiments are given in Table VI. It is clear from these data that the alloxan-diabetic rats were actually less susceptible than normal rats.

Mechanism of action

The narcotic actions studied here are probably a direct action of the fatty acid anion on the cen- 
TABLE IV

The effect of intraperitoneal injection of sodium butyrate and sodium valerate on nephrectomized rats

\begin{tabular}{|c|c|c|c|c|c|c|}
\hline $\begin{array}{l}\text { Rat } \\
\text { no. }\end{array}$ & Fatty acid & Conc. & $\begin{array}{l}\text { Amount } \\
\text { injected } \\
\mathbf{m M / K \boldsymbol { g } .}\end{array}$ & Response & $\begin{array}{c}\text { Time } \\
\text { until } \\
\text { unconsc. } \\
\text { minutes }\end{array}$ & $\begin{array}{c}\text { Duration } \\
\text { of } \\
\text { unconsc. } \\
\text { minutes }\end{array}$ \\
\hline $\begin{array}{l}200 \\
201 \\
202\end{array}$ & Butyrate & 0.95 & $\begin{array}{l}15.0 \\
15.0 \\
20.0\end{array}$ & $\begin{array}{l}\text { None } \\
\text { None } \\
\text { Unconsc. }\end{array}$ & 11 & 10 \\
\hline $\begin{array}{l}203 \\
204 \\
205 \\
206 \\
207 \\
208 \\
209 \\
210\end{array}$ & Valerate & 1.0 & 19.5 & $\begin{array}{l}\text { None } \\
\text { None } \\
\text { Unconsc. } \\
\text { Unconsc. } \\
\text { Unconsc. } \\
\text { Unconsc. } \\
\text { Unconsc. } \\
\text { Unconsc. }\end{array}$ & $\begin{array}{r}28 \\
24 \\
24 \\
18 \\
18 \\
9\end{array}$ & $\begin{array}{r}4 \\
2 \\
30 \\
10 \\
22 \\
60\end{array}$ \\
\hline
\end{tabular}

tral nervous tissue. The electroencephalographic changes which occur during the unconscious state support this idea (19). The fatty acid salts may inhibit the metabolic activity of cerebral tissue as they do muscle (6) and yeast (1). Several properties characterize their inhibition of yeast cell metabolism: 1 . A nonspecificity, as evidenced by the large number of reactions affected, 2 . An increasing action with an increase in chain length, 3. A reduction of the inhibitory action when a hydroxyl or carboxyl group is introduced into the hydrocarbon part of the molecules, 4 . A reversibility.

The similarity of these properties with those demonstrated in the present study is certainly striking. However, this similarity does not necessarily mean that the cellular mechanism of action is the same in the two situations.

\section{SUMMARY}

Injection of the neutralized short chain fatty acids will produce unconsciousness in experimental animals. The amount of the fatty acid which will produce this response decreases with an increase in chain length. Further, the amount which will produce a loss of consciousness for a given fatty acid depends upon the concentration and the site of injection. The introduction of an $(\mathrm{OH})$ group into the carbon chain reduces the narcotic action.

TABLE $v$

The effect of intraperitoneal injection of sodium lactate, sodium $\beta$-hydroxybutyrate and acetone on rats

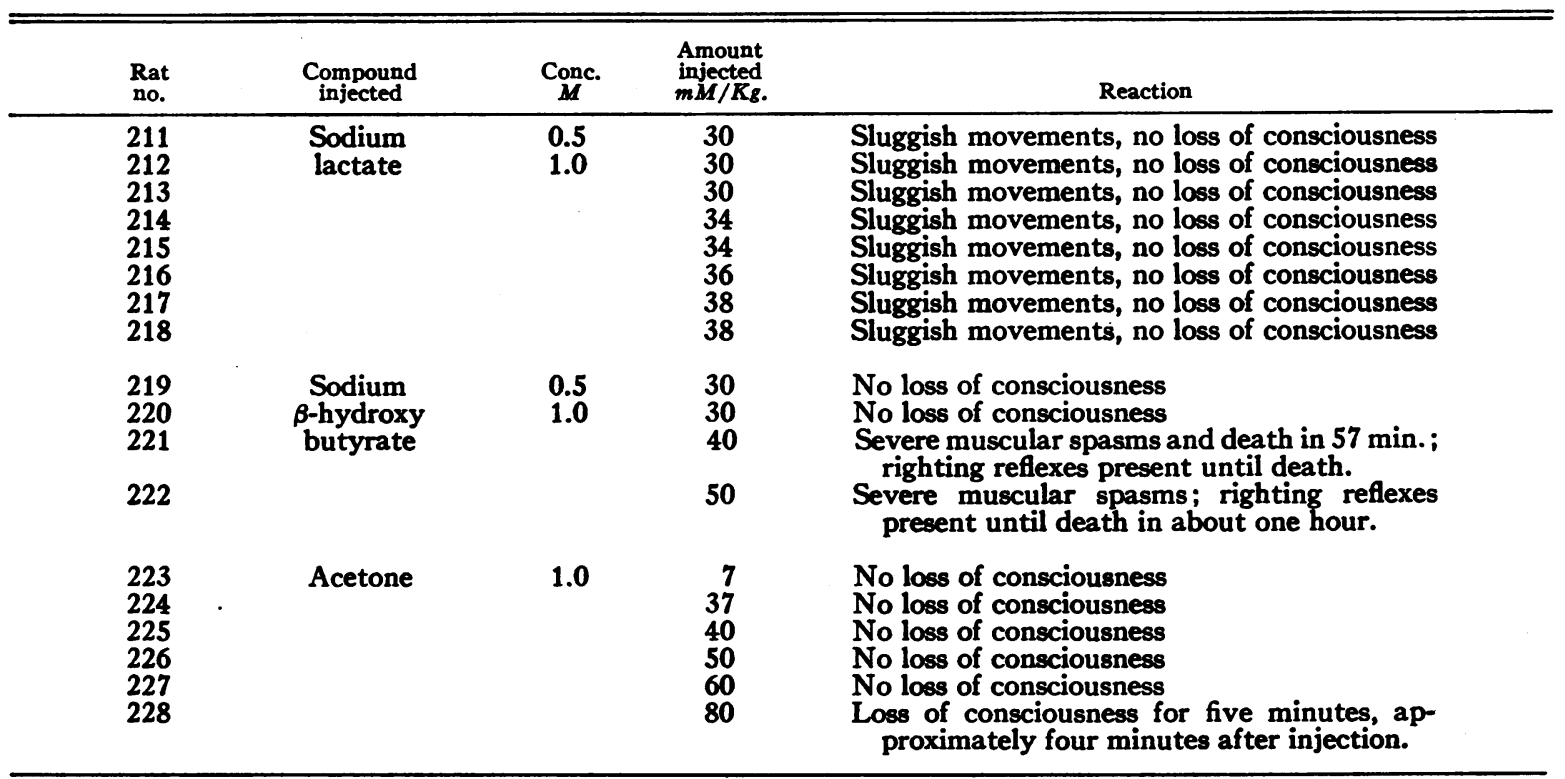


TABLE VI

The effect of intraperitoneal injection of sodium valerate on alloxan-diabetic rats

\begin{tabular}{|c|c|c|c|c|c|c|}
\hline $\begin{array}{l}\text { Rat } \\
\text { no. }\end{array}$ & Fatty acid & Conc. & $\begin{array}{l}\text { Amount } \\
\text { injected } \\
\mathbf{m M / K} .\end{array}$ & Response & $\begin{array}{c}\text { Time } \\
\text { until } \\
\text { unconsc. } \\
\text { minutes }\end{array}$ & $\begin{array}{c}\text { Duration } \\
\text { of } \\
\text { unconsc. } \\
\text { minutes }\end{array}$ \\
\hline $\begin{array}{l}229 \\
230 \\
231 \\
232\end{array}$ & Valerate & 0.5 & 18 & $\begin{array}{l}\text { None } \\
\text { None } \\
\text { None } \\
\text { None }\end{array}$ & & \\
\hline $\begin{array}{l}233 \\
234 \\
235 \\
236\end{array}$ & & & 20 & $\begin{array}{l}\text { None } \\
\text { None } \\
\text { None } \\
\text { Unconsc. }\end{array}$ & 20 & 6 \\
\hline $\begin{array}{l}237 \\
238 \\
239 \\
240\end{array}$ & & & 22 & $\begin{array}{l}\text { None } \\
\text { None } \\
\text { Unconsc. } \\
\text { Unconsc. }\end{array}$ & $\begin{array}{l}28 \\
16\end{array}$ & $\begin{array}{r}4 \\
20\end{array}$ \\
\hline $\begin{array}{l}241 \\
242 \\
243\end{array}$ & & & 24 & $\begin{array}{l}\text { Unconsc. } \\
\text { Unconsc. } \\
\text { Unconsc. }\end{array}$ & $\begin{array}{l}38 \\
22 \\
16\end{array}$ & $\begin{array}{r}2 \\
6 \\
12\end{array}$ \\
\hline
\end{tabular}

There is no hemolysis from the amount of fatty acid which will produce unconsciousness. Nephrectomy does not seem to alter the duration of the narcotic action.

It is suggested that the mechanism of action at the cellular level may be the same as that in the fatty acid inhibition of yeast metabolism.

\section{REFERENCES}

1. Samson, F. E., Katz, A. M., and Harris, D. L., Effects of acetate and other short-chain fatty acids on yeast metabolism. Arch. Biochem., 1955, 54, 406.

2. Baker, Z., Harrison, R. W., and Miller, B. F., Action of synthetic detergents on the metabolism of bacteria. J. Exper. Med., 1941, 73, 249.

3. Stanley, W. M., Coleman, G. H., Green, C. M., Sacks, J., and Adams, R., Bacteriological action of certain synthetic organic acids toward mycobacterium leprae and other acid-fast bacteria. J. Pharmacol. \& Exper. Therap., 1932, 45, 121.

4. Karabinos, J. V., and Ferlin, H. J., Bactericidal activity of certain fatty acids. J. Am. Oil Chem. Soc., 1954, 31, 228.

5. Keeney, E. L., Lankford, E., and Ajello, L., The bacteriostatic and bactericidal effects of fatty acid salts on bacteria in broth cultures. Bull. Johns Hopkins Hosp., 1945, 77, 437.

6. Hansen, R. G., and Rutter, W. J., Fatty acid metabolism of rat diaphragm. J. Biol. Chem., 1952, 195, 121.

7. Mayer, H., Untersuchungen über eine toxische Wirkung der niederen Fettsäuren. Arch. f. exper. Path. u. Pharmakol., 1886, 21, 119.
8. Wilbur, R. L., Acidosis. Experimental evidence that its nervous symptoms are not wholly due to lack of alkali. J. A. M. A., 1904, 43, 1228.

9. Allen, F. M., and Wishart, M. B., Experimental studies in diabetes. Ser. V. Acidosis, 9. Administration of acetone bodies and related bodies. J. Metab. Research, 1923, 4, 613.

10. Dungan, A. R. J., Experimental observations on the acetone bodies. J. Metab. Research, 1924, 6, 229.

11. Fisher, $P$., The role of ketone bodies in the etiology of diabetic coma. Am. J. M. Sc., 1951, 221, 384.

12. Farris, E. J., and Griffith, J. Q., Jr., The Rat in Laboratory Investigation. Philadelphia, J. B. Lippincott, 1949, p. 446.

13. Reid, R. L., and Lederer, M., Separation and estimation of saturated $\mathrm{C}_{2}-\mathrm{C}_{7}$ fatty acids by paper partition chromatography. Biochem. J., 1951, 50, 60.

14. Marsh, D. F., Outline of Fundamental Pharmacology. Springfield, Charles C Thomas, 1951, p. 20.

15. Ulrich, J. L., and Shternov, V. A., The comparative action of hypertonic solutions of the chlorates and chlorides of potassium, sodium, calcium, and magnesium. J. Pharmacol. \& Exper. Therap., 1929, 35, 1.

16. Breusch, F. L., and Bodur, H., Seifenhämolyse und Fettsäurekonstitution. Ztschr. f. physiol. Chem., 1950, 286, 148.

17. Mirsky, I. A., Futterman, P., Wachman, J., and Perisutti, G., The influence of pancreatectomy on the metabolic state of the alloxan-diabetic dog. Endocrinology, 1951, 49, 73.

18. Cagan, R. N., Sobel, A. E., Nichols, R. A., and Loewe, L., Serum lipids in normal and alloxan diabetic rats. Metabolism, 1954, 3, 168.

19. White, R. P., and Samson, F. E., Effects of fatty acid anions on the electroencephalogram of unanesthetized rabbits. Am. J. Physiol., In press. 